Studies in African Linguistics

Volume 42, Number 1, 2013

\title{
DEMARCATING EMAI DATIVE CONSTRUCTIONS
}

\author{
Ronald P. Schaefer \& Francis O. Egbokhare \\ SIU Edwardsville University of Ibadan
}

\section{Introduction}

This paper investigates the formal and functional character of a dative relation and two additional structural relations in Emai, an Edoid language of West Benue Congo stock (Bendor-Samuel 1989, Williamson and Blench 2000). Each relation is grammatically expressed by a common morphophoneme. Postverbal particle li/ni marks Emai dative constituents. In addition, li/ni codes a limited range of subordinate clause types within complex sentences, and within noun phrases it designates a subset of modifying constituents. To bridge the common formal marking across these structural relations, we postulate their identification of a semantic ground type (within a figure-ground complex) characterized by spatial collectivity and temporal continuity. Our overall conclusion thus pertains to the function of perspective taking in grammar and its formal marking (Talmy 2000), with special emphasis placed on the dative relation.

Emai is a relatively strict SVO language. It employs grammatical tone across clauses characterized by verb serialization, verb plus postverbal particle or a combination of the two. ${ }^{1}$ Since prepositions and inflectional morphology are rare in Emai, it exhibits no passivization and minimal diathesis alternation of verb arguments.

\section{Grammatical marking by $l i / n i$}

Emai utilizes the morphophoneme li/ni to signal a range of structural relations. Among these is the dative. Additional relations grammatically expressed by $l i / n i$ are clause

\footnotetext{
${ }^{1}$ Orthographic conventions for Emai are consistent with those in Schaefer and Egbokhare (2007), where $\underline{o}$ represents a lax mid back vowel, $\underline{e}$ a lax mid front vowel, and $v b$ a voiced bilabial approximant. High tone is marked by an acute accent, low tone by a grave accent, and high downstep by an acute accent followed by an apostrophe.
} 
subordination and nominal modification. Although dative is our principal focus, we consider subordination and modification in order to investigate whether these relations have a common semantic character.

Emai marks a dative relation with a postverbal applicative (APP) particle $l i / n i$ that takes a [+human] noun phrase complement (e.g. émeè).

$$
\begin{aligned}
& \text { òjè rée éghó' ní } \underline{\underline{e} m \underline{e} .} . \\
& \text { Oje take money APP me } \\
& \text { 'Oje gave money to me.' }
\end{aligned}
$$

This particle has no synchronic verb as a counterpart, as is evident in the Emai lexical entries of Schaefer and Egbokhare (2007) and as revealed by analysis of Emai double object verbs (Schaefer and Egbokhare 2003a), which tend to encode events of forceful, physical contact, and of alignment relations (Schaefer and Egbokhare 2010b), where zero coding of ditransitive theme and monotransitive patient align relative to li/ni marking of recipient.

The Emai applicative particle is registered orthographically as either $l i$ or $n i .^{2}$ The form $l i$ occurs when the dative complement, invariably [+human], is a lexical noun.

óli òkpòsò shén óli émà lí àlèkè.
the woman sell the yam APP Aleke
'The woman sold the yam to Aleke.'

The $n i$ form appears when the dative complement assumes a pronominal shape (3a) or when the complement occurs in clause-initial focus position, for example (3b).
a. ólì òkpòsò shén ólí émà ní áìn. the woman sell the yam APP her 'The woman sold the yam to her.'

b. àlèkè lí ólí ókpósó shén' ólí émà ní. Aleke PF the woman sell the yam APP 'It was Aleke that the woman sold the yam to.'

\footnotetext{
${ }^{2}$ Abbreviations used throughout this paper include the following: APP=applicative, ASS=associative, $\mathrm{C}=$ continuous, $\mathrm{CL}=$ change of location, $\mathrm{CON}=$ conative, $\mathrm{CS}=$ change of state, $\mathrm{DS}=$ distributive, $\mathrm{F}=$ factative, $\mathrm{H}=$ habitual, $\mathrm{HOR}=$ hortative, $\mathrm{IND}=$ indicative, $\mathrm{LOC}=$ locative, $\mathrm{NEG}=$ negative, $\mathrm{PF}=$ positive focus, $\mathrm{PRED}=$ predictive, $\mathrm{PRT}=$ particle, $\mathrm{PUR}=$ purposive, $\mathrm{R}=$ relator, $\mathrm{RES}=$ resultative, $\mathrm{SC}=$ subject concord, $\mathrm{SEQ}=$ sequential, $\mathrm{SUB}=$ subsequent, $\mathrm{SUBJ}=$ subjunctive.
} 
Applicative $l i / n i$ governs a class of pronouns, exemplified by second person $a(4 \mathrm{a})$, that are distinct from direct object pronouns $(4 \mathrm{~b}-\mathrm{c})$ and, for that matter, deictic locative pronouns $(4 d){ }^{3}$

a. ólì òkpòsò shén ólí émà ní á.

the woman sell the yam APP you

'The woman sold the yam to you.'

b. óli ighómòghbómó $\quad s h \underline{e} n^{\prime} \underline{e}$.

the kidnapper sell you

'The kidnapper sold you.'

c. *óli òkpòsò shén ólí émà ní é.

the woman sell the yam APP you

'The woman sold the yam to you.'

d. *ólì òkpòsò shén óli émà ní èvbò.

the woman sell the yam APP there

'The woman sold the yam to that place yonder.'

A comprehensive listing of indirect object and direct object pronominal forms by person and number is arranged below. A formal distinction among these forms is particularly evident in second and third person singular.

Indirect Object Pronouns

$$
\text { singular plural }
$$

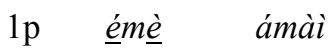

$2 \mathrm{p} \quad \dot{a} \quad \dot{a} v b \grave{a}$

$3 \mathrm{p}$ aìn iyàìn
Direct Object Pronouns

singular plural

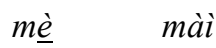

$\underline{e} \quad v b \grave{a}$

ól ínàì

The Emai $l i / n i$ form is a member of a closed class of postverbal particles prototypically conveying event change: change of state (CS) $a$ (5a), change of location (CL) $\underline{o}$ (5b) and change of possession $l i / n i(5 \mathrm{c})$. In event change constructions, the tone of the postverbal

3 Emai's deictic locative pronouns include ààn 'right here,' ááìn 'right there,' èàn 'over here,' éáìn 'over there,' and èvbò 'there yonder.' 
particle as well as the tone of the verb vary according to clause level polarity, mood and aspect (Schaefer \& Egbokhare 1999b).

a. ólí óvbèkhàn gbé ólí ákhè á. the youth break the pot CS

'The youth broke the pot.'

b. ólì òkpòsò kú évbì ó vbi émàè. the woman pour palm.oil CL LOC food 'The woman poured palm oil onto the food.'

c. ólì òkpòsò háé ósà lí ólì ònwìmè. the woman pay debt APP the farmer 'The woman paid a debt to the farmer.'

Change of state and change of location particles each combine with applicative $l i / n i$.

a. àlèkè ò ó fòò ólí ómí á lì ólí ómò․ Aleke SC C cool the soup CS APP the child 'Aleke is cooling down the soup for the child.'

b. òjè ré óbò ó vbi ébè li àlèkè. Oje take finger CL LOC paper APP Aleke 'Oje signed / put his mark on the paper for Aleke.'

There are constructions in Emai other than those marked by $l i / n i$ that require a [+human] noun phrase. Among these are allative (ólì ònwimè 7a), source (ólì òkpòsò 7b), replacive (ólí ómòhè 7c) and comitative (ojé $7 \mathrm{~d}$ ). Some have English translation equivalents marked by 'to' or 'for,' but others translate as 'with' or 'from.' However, none of these noun phrase positions accepts an indirect object pronoun.

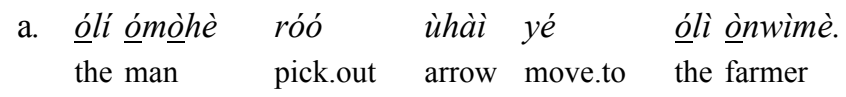

'The man took an arrow to the farmer.'

b. ólí ómóhé dế émá vbí óbó isì ólì òkpòsò. the man buy yam LOC hand ASS the woman

'The man bought yam from the woman.' 
c. óli ómọhè kpáyé àlèkè gbé ólí ófè. the man replace Aleke kill the rat 'Instead of Aleke, the man killed the rat.'

d. ólí ómọhè $\underline{o}$ ó kpàyè ójé dán. the man SC C accompany Oje wrestle 'The man is wrestling with Oje.'

Additional structural relations are designated by the form $l i / n i$. It signals rhetorical questions in discourse, subordinate clauses relative to main clauses in complex sentences, and modifying constituents relative to head units within noun phrases. Regarding discourse, $l i / n i$ is one element of a grammatical complex signaling purposive rhetorical interrogatives. Purposive (PUR) li/ni occurs in construction with the question word émé' 'what' (8a). Since no responses are expected for such questions, they are tightly integrated into discourse context. They contrast with information questions (8b), which incorporate an explicit 'cause' verb (ze $)$ and indicative $(k h i)$ marked sentence complement.

a. émé ójé dúé ábò lí àlèkè ní? what Oje rub hands APP Aleke PUR 'What did Oje plead with Aleke for?'

b. émé $\underline{o}$ zée-í khi ójé dúé ábò lí àlèkè? what it cause-F IND Oje rub hands APP Aleke

'Why did Oje plead with Aleke?'

$\mathrm{Li} / \mathrm{ni}$ also designates adjunct clauses of purpose and result. Compared to other adjunct clauses, purpose and result constrain subject reference as well as mood. Both require a pronoun in subject position that is coreferential with either main clause subject or direct object. Their subject pronoun must also exhibit right edge high tone; low tone is ungrammatical. Neither clause allows perfect or imperfect aspect. Relative to their accompanying main clause, purpose and result clauses reveal a high degree of both spatial collectivity through participant coreference and temporal continuity through an obligatory irrealis condition. Purpose clauses, for example, require subjunctive marking with conative (CON) preverb óó (9a) or hortative (HOR) auxiliary $i(9 \mathrm{~b})$.

$\begin{array}{lllllllll}\text { a. òjè } & k h u ́ & \text { óli áwà } & \text { lí } & \underline{o} & i & \underline{o o ́} & \text { è } & \text { ólí éànmì } \\ \text { Oje } & \text { chase } & \text { the } \operatorname{dog} & \text { PUR } & \text { it } & \text { NEG } & \text { CON } & \text { eat the food }\end{array}$

'Oje chased the dog in order that it not go to eat the food.' 
b. òjè gbé óli óókhò li $\underline{\text { ó }} i$ kpè mié éànmì è. Oje kill the chicken PUR he HOR SUB find meat eat 'Oje killed the chicken in order to find meat to eat.'

Result clauses with $l i / n i$ require concessive (CONC) auxiliary re $(10 \mathrm{a})$. They manifest a temporally durative character (evidenced by 'until' in translation) in contrast to the punctual, discrete nature of events in a corresponding serial verb construction, contrast (10a) with (10b).

$\begin{array}{llllll}\text { a. òjè gbé àlèkè li } & \underline{o} \text { rè } & u \\ \text { Oje } & \text { beat Aleke } & \text { RES } & \text { she CONC } & \text { die }\end{array}$

'Oje beat Aleke until she died. / *Oje killed Aleke.'

b. òjè gbé àlèkè ú.

Oje beat Aleke die

'Oje beat Aleke and she died.'

An additional subordinate clause type designated by $l i / n i$ serves as a sentence (S) complement. In contrast to $k h i$ marked S-complements with indicative (IND) mood (11a), li/ni S-complements require subjunctive (SUBJ) mood (Schaefer \& Egbokhare 2007). With obligatory right edge high tone on the grammatical subject (éli ivbékhán 'the children') and low tone on the initial verb phrase element ( $\dot{e}$ 'eat'), $l i / n i$-marked subjunctive complements exhibit temporal continuity relative to their main clause (11b).
a. àlèkè één-i khi éli ivbèkhàn é óli émàè. Aleke know-F IND the youths eat the food

'Aleke knew that the youths have eaten the food.'
b. àlèkè ò ó hòo li éli ivbékhán è óli émàè. Aleke SC C want SUBJ the youths eat the food 'Aleke wants the youths to eat the food.'

Structural relations marked by $l i / n i$ also occur within noun phrases. As a relator (R) particle positioned after a head constituent, $l i / n i$ complements establish a spatial and temporal continuum bound to the head noun. Li/ni links a relative clause (ó gbé óli éwè) to its head noun (óvbékhán) in (12a) or an attributive phrase (ébín') to its head noun (éwé) in (12b).

a. òjè záwó ólí óvbékhán lí $\underline{\underline{o}}$ gbé
Oje see óli éwè.

'Oje saw the youth who killed the goat.' 


\section{b. éli éwé lí ébin' the goats $\mathrm{R}$ dark 'the dark goats'}

With numeral complements, $l i / n i$ distinguishes collective from distributive expressions. It establishes a collective interpretation, bringing the whole of a quantity into perspective, compared to the distributive interpretation of bare (unmarked by $l i / n i$ ) numeral complements. In addition, a collective li/ni expression induces high tone spread on its head noun (imóhé) and relies on English translation with 'group of, collection of,' whereas a head noun followed by a numeral unmarked by $l i / n i$ receives lexical tone (imòhè) and a non-collective, distributive translation:

\begin{tabular}{|c|c|c|}
\hline $\begin{array}{l}\text { ímóhé lì èvá } \\
\text { men R two } \\
\text { 'group of two men' }\end{array}$ & $\begin{array}{l}\text { imóhé li ógbàn } \\
\text { men R thirty } \\
\text { 'group of thirty men' }\end{array}$ & $\begin{array}{l}\text { imóhé lì èélé } \\
\text { men } \mathrm{R} \text { four } \\
\text { 'group of four men' }\end{array}$ \\
\hline Ímòhè èvá & imòhhè ógbàn & ímòhè èélé \\
\hline two & thirty & men \\
\hline two me & 'thirty men' & 'four men' \\
\hline
\end{tabular}

$\mathrm{Li} / \mathrm{ni}$ marks not only collective numeral complements in noun phrases. It links head nouns to durative temporal complements. Relative to day-unit nominals, li/ni only accepts odè 'yesterday' (13a). Corresponding expressions with éènà 'today' and ákhò 'tomorrow' are ungrammatical (13b). ${ }^{4}$
a. ópíá lì òdè
cutlass $R$ yesterday
'yesterday's cutlass / the cutlass from yesterday'
b. *ópiá lí éènà /ákhò cutlass $\mathrm{R}$ today tomorrow
'today's cutlass / tomorrow's cutlass'

Complements defined by òdè do not attribute a physical property to a head noun; rather, they provide a temporal vantage point from which to identify the head noun referent. The

\footnotetext{
${ }^{4}$ Collective phrases with their wholistic character are distinct from possession phrases. Emai possession is typically marked by the associative (ASS) particle isi, where possessum precedes possessor (Schaefer 1999), e.g. áwá isì òjè [dog Ass Oje] 'dog of Oje'.
} 
more durative, fixed temporal frame provided by òdè 'yesterday,' compared to éènà 'today' and ákhò 'tomorrow,' establishes the necessary temporal continuity of part and whole that parallels the spatial co-location of collective numeral expressions with li/ni. Indeed, temporal continuity and spatial collectivity of a subordinate or modifying structural part relative to a complex sentence or noun phrase whole define common elements of a particular type of ground perspective. These elements are fundamental to li/ni marking; they allow a common vantage point from which to view a main clause or a head noun, and, as we will see shortly, a subject-verb-direct-object or a subject-verb predication.

\section{Theoretical background for dative}

"Dative" has received typological attention from various sources. Palmer (1994) advances it as a grammatical relation more neutral than "indirect object," thus making it equally applicable to noun phrases in accusative and ergative systems. Palmer's dative relation is prototypically linked to either of the semantic roles recipient or beneficiary. Most often, these roles are limited to noun phrases headed by human nouns. In addition, Palmer also acknowledges dative marking of event participants "indirectly affected" or "less fully affected" by an action.

Dative receives further characterization in Blake (2001:143). It is the primary "noncore" case in his review of grammatical case systems and their semantic roles. His list of grammatical relations for dative reveals its frequent link to indirect object:

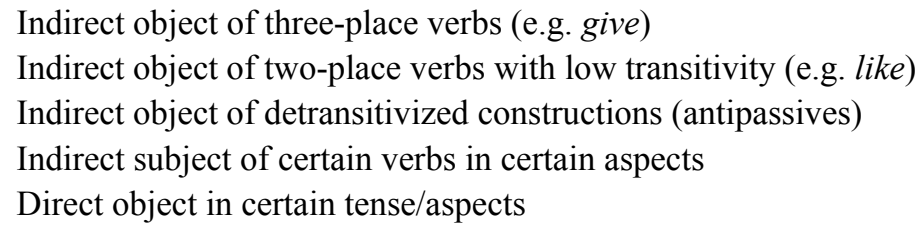

Blake's list of semantic roles for dative-marked noun phrases (shown below) agrees in large measure with Palmer. "Beneficiary" is recognized by both. Blake's "destination" seems akin to but broader than Palmer's "recipient"; "possessor" appears to be an addition.

\section{Beneficiary (on behalf of) or purpose \\ Destination (as opposed to allative) \\ Possessor}

Lists of this sort certainly have utility for heuristic purposes and for the identification of crosslinguistic possibilities. Even at a very general level, however, they provide little insight into possible combinations of grammatical relations and semantic roles that can arise through common grammatical articulation in individual linguistic systems. Within a single language 
for instance, do each of the grammatical relations indirect object and direct object realize each of the semantic roles beneficiary and destination? Alternatively, does the indirect object relation accept the roles beneficiary, destination and possessor? Does grammatical relation in any way constrain appearance of these roles?

As an initial step toward addressing questions of this nature, consider the languages of West Africa, where the coding of dative is non-uniform for 'give' type events. The dative notion and its prototypic recipient semantic role are coded as direct object, object of a verb in a series, or as first verb in a double object construction. Emai's neighbor to the west, Yoruba, articulates 'give' type expressions with either a verb plus particle construction or a serial verb construction (Atoyebi, Haspelmath, and Malchukov 2010; Lord 1993). As sole verb of a 'give' predication (14a), the form fun takes a direct object expressing recipient in construction with particle $n i$ taking a nominal conveying a theme role. Fun also occurs as a coverb in series with a range of verbs, e.g. ta 'sell,' and marks recipient (14b) in addition to beneficiary and addressee.
a. bólá fún adé ní iwé.
Bola give Ade PRT book
'Bola gave Ade a book.'

b. wón ta ókó náà fun àdé. they sell farm the give Ade

'They sold the farm to Ade.'

Emai's neighbor to the east, Igbo, expresses 'give' type expressions exclusively in a double object contruction with the first object realizing recipient and the second object theme (Uwalaka 1988).
a. àdha nyè-rè ucè egho.
Adha give-past Uce money
'Adha gave Uce money.'
b. ùghò kuzii-ri ojhì or $\underline{u}$.
Ugho teach-past Ojhi trade
'Ugho taught Ojhi a trade.'

Into this complex of coding strategies, we bring Emai. We analyze the range of semantic roles associated with dative-marked nominals. Our data emanate from on-going documentation incorporating oral narrative texts (Schaefer \& Egbokhare 1999) as well as dictionary (Schaefer \& Egbokhare 2007) and grammar description (Schaefer \& Egbokhare nd). 
3.1 Analysis of Dative. Emai's $l i / n i$ particle frames a dative grammatical relation. $L i / n i$ combines with verbs of object manipulation such as $z \underline{e}$ 'scoop,' roo 'pick out' and vo 'fetch' to convey possession transfer of a direct object referent from one participant to another (Schaefer 2000). ${ }^{5}$ In these constructions, translated with English 'give,' li/ni marks the transfer to event recipient.

a. ólì òkpòsò zé émàè lí ólì ònwìmè.

the woman scoop food APP the farmer

'The woman gave food to /scooped food for the farmer.'

b. ólì òkpòsò róó ólì ùhàì lí ólì ònwìmè.

the woman pick.out the arrow APP the farmer

'The man gave the arrow to / picked out the arrow for the farmer.'

c. ólí ómòhè vó óràn lí óli ókpósódiòn.

the man fetch wood APP the old.woman

'The man gave wood to / fetched wood for the old woman.'

It is important to recognize that these verbs do not convey a 'give' relation without $l i$. They convey simple object manipulation for events of scooping, picking out, or fetching.
a. ólì òkpòsò zé émàè.
the woman scoop food
'The woman scooped food.'

b. ólì òkpòsò róó ùhài.

the woman pick.out arrow

'The man picked out an arrow.'

c. ólí ómọhè vó óràn.

the man fetch wood

'The man fetched wood.'

Dative marking is not limited to expressions of possession change involving recipients. Datives occur where no grammatically expressed referent transfers from one participant to

\footnotetext{
${ }^{5}$ To reiterate a point made earlier, the form $l i / n i$ has no verbal counterpart meaning 'give' in transitive constructions (e.g. *ólì ókpòsò lí émàè 'The woman gave food') or as a verb in a double object construction (e.g. óli òkpòsò lí ójé émàè 'The woman gave Oje food').
} 
another. In these constructions $l i / n i$ marks semantic beneficiary: one who benefits from event occurrence.

a. $\underline{\text { óli } \underline{v} v b e ̀ k h a ̀ n} f i \quad$ àgbò lí ólì òkpòsò. the youth blow flute APP the woman 'The youth blew a flute for the woman.'

b. éli ivbèkhàn $\underline{o}$ ó gbè ábó lì òjè. the youths SC C hit hands APP Oje 'The youths are clapping their hands for Oje.'

c. ólì óvbèkhàn ráá òtọi nì émèe. the youth smoothen ground APP me 'The youth smoothened the ground for me.'

Transitive verbs conveying entity transfer to a human participant do not uniformly accept $l i / n i$. Verbs like $f i$ 'throw' and bume 'fling,' that convey ballistic change of position rather than change of possession, do not admit li/ni. Instead, they require an allative construction, noted above in (7a) and shown as $(19 \mathrm{~b}, 19 \mathrm{~d})$, where verb in series ye marks a human noun as recipient of a re-positioned object. ${ }^{6}$

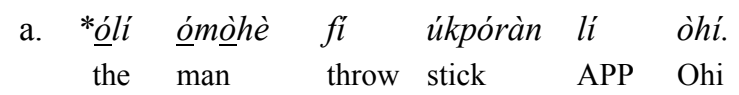

'The man threw a stick to Ohi.'

b. óli ómòhè fí úkpóràn yé òhí.

the man throw stick move.to Ohi

'The man threw a stick to Ohi.'

c. *ólí ómòhè búmé àgá lí òhí.

the man fling chair APP Ohi

'The man flung a chair to Ohi.'

d. óli ómòhè búmé àgá yé òhí.

the man fling chair move.to Ohi

'The man flung a chair to Ohi.'

\footnotetext{
${ }^{6}$ Allative constructions appear to utilize the change of location verb ye 'move toward' (óli ómòhè yé ìwè

'The man moved toward the house'), which has similar phonological shape and a related semantic sense.
} 
Dative and allative constructions where $l i / n i$ and $y e$ stand in minimal contrast reveal some of their distinguishing properties vis-à-vis object transfer. Important among these is durativity. $l i / n i$ assumes a permanent object transfer (i.e. possession change) compared to ye's more temporary object transfer (i.e. location or position change). This distinction, evident in contrasting constructions employing the same main clause verb (e.g. $n w u$ 'take hold of'), is reflected in their respective English translations: 'give' for $l i / n i$ and 'take' for $y e$.



'The woman gave yam to the farmer.'

b. ólì òkpòsò nwú émà yé ólì ònwìmè.

the woman take.hold yam move.to the farmer

'The woman took yam to the farmer.'

Dative and allative constructions exhibit contrasting implications with respect to the colocation of participants. (20a) implies (21a) (the farmer to whom the yam is given and the woman subject exist in a relation of physical co-location) not (21b), whereas (20b) implies not (21a) but (21b), the farmer to whom the yam is taken and the woman exist in a relation of dislocation.

a. ólì ònwìmè rî̀ vbi ááìn. the farmer be LOC right.there 'The farmer is right there.'

b. ólì ònwìmè $i \quad i \quad e ̀ r$ vbíáin. the farmer SC NEG be LOC right.there 'The farmer is not right there.'

Dative relations expressed by Emai's applicative li/ni particle are not limited to transitive verbs. They are found with intransitive verbs as well. The resulting constructions tend to manifest readings where $l i / n i$ marks a beneficiary $(22 \mathrm{~b}-\mathrm{g}$ ), although recipient also seems to occur. While spatial collectivity of participants and temporal continuity of event elements are not physically required for beneficiary readings, they are conceptually evident. At times, it is difficult to distinguish between beneficiary and recipient, especially when one begins to construe grammatically unexpressed elements as transferring from one participant to another (i.e., entities brought about through érómó 'prayers' in $(22 \mathrm{~g})$ where the verb is se 'be sufficient'). With a recipient reading, (22a) implies that a possession relation will exist at some future time between subject and dative participants, the subject as possessum and dative as possessor, i.e ó ká isì èmé [maize ASS mine] 'maize of mine.' With a benefactive reading, 
(22a) implies that, between these same participants, a relation presently exists that will benefit the dative marked participant.
a. $\underline{\text { ólí }} \underline{\underline{a} k a ̀} \quad s \underline{e}$

$\underline{e}$
$n i \quad \underline{e} m \underline{e}$.
the maize be.sufficient APP me
'The maize is sufficient for me.'

b. ọhi bián li ólì òkpòsò.

Ohi work APP the woman

'Ohi worked for the woman.'

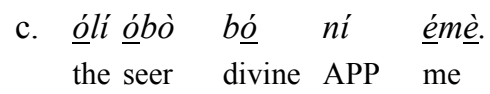

'The seer divined for me.'

d. yàn á sié lì òjè. they $\mathrm{C}$ play APP Oje

'They are playing for Oje. / They are entertaining Oje.'

e. ólì òkpòsò déé rè lí ólí ómò. the woman lower arrive APP the child 'The woman bent down for the child.'

f. yán rúóó lí égbè. they boast APP each.other 'They boasted for each other (to do it).'

g. érómó isì ójé èrèmé sée $\underline{e}^{\prime} \quad n i \quad$ áin. prayers ASS Oje all be.sufficient APP him 'All Oje's prayers came true for him / were answered.'

3.2. Some Complexities of Possessional Functions. While dative $l i / n i$ designates recipients and characterizes possession change, it sometimes does so for verbs that inherently appear incompatible with recipient. An inversion with respect to the linking of grammatical relations and semantic roles, for instance, affects the verb momo. In simple transitive structures it has the sense of 'borrow.' 
(23)

óli ómọhè mómó óli ìmátò.

the man borrow the car

'The man borrowed the car.'

Maintaining this meaning, momo accepts vbi óbò designating the source or pre-event possessor (óli ònwimè), while direct object conveys possessum (úvbiágháé). Subject expresses a temporary recipient or post-event possessor (óli ómóhhè).
ólí ómòhè
mómó úvbiágháé
$v b i$
óbó isi
ólì ònwimè.
the man
borrow knife
LOC hand
ASS the farmer
'The man has borrowed a knife from the farmer.'

When momo and li/ni frame a construction, the sense is 'lend/loan to' (25), the converse of 'borrow.' The dative complement of li/ni designates recipient or post-event possessor (ojè), subject the source or pre-event possessor (óli ònwimè), and direct object the possessum (éghó).

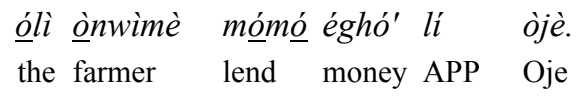

'The farmer lent money to Oje / loaned money to Oje.'

Sense change or semantic inversion of this type is not generally true of transfer verbs or verbs of financial transaction. ${ }^{7}$ The verb de 'buy,' without a change in sense, marks source with vbi óbo 'from' and recipient with li/ni 'to.'


'The man bought yam from the farmer.'

b. óli ómòhè dé émà lí ólì ònwìmè. the man buy yam APP the farmer 'The man bought yam for the farmer.'

\footnotetext{
${ }^{7}$ Among postverbal particles, it is not only $l i / n i$ that induces sense change in the verb. A similar semantic effect is engendered by the change of state particle $a$. The verb khuye in simple transitive structures conveys the sense 'close' (óli ómòhè khúyé ìwiìndò 'The man closed the window'). In construction with the change of state particle $a$, khuye expresses the sense 'open' (óli ómòhè khúyé iwiìndò à 'He opened up a window').
} 
Another issue of semantic interpretation bearing on possession and affecting dative constructions occurs with verbs of tieing and itching. Uniformly, these verbs mark beneficiary with $l i / n i(27 \mathrm{a}-\mathrm{b})$.

$\begin{array}{lllll}\text { a. } \underline{\underline{o} l i} \underline{\text { ómòhhè }} & z \underline{e} & \text { étò } & \text { lí } & \text { inyó } \\ \text { the man } & \text { shave } & \text { hair } & \text { APP } & \text { mother his }\end{array}$

'The man shaved his hair (in observance of) for his mother.'

b. ólì òkpòsò gbá ògbè̀lè lí òjè. the woman tie baby.sash APP Oje

'The woman tied on her baby sash for Oje (tied the sash on herself).'

They also maintain a possession relation that existed prior to event onset. This lack of possession change leads to a beneficiary rather than recipient interpretation. For recipient readings, a direct object possessum and a li/ni possessor are disjoint prior to an event but adjoined after the event. For beneficiary readings, an adjoined relation between subject possessor and direct object possessum exists both before and after the event. Let's call this the prototypical beneficiary reading.

Emai also exhibits non-prototypical beneficiary readings. Relevant constructions show a possession relation holding between direct object possessum and $l i / n i$ possessor throughout an event. Each example in (28) assumes and maintains a possession relation between direct object possessum and $l i / n i$ possessor. The $l i / n i$ complement serves as beneficiary, with no change of possession taking place. Significantly, the possessum in these constructions is a body-part or body-part related term, although, as (27a) above indicates, body-part terms alone are not sufficient to induce the non-prototypical beneficiary reading.

(28) a. óli óvbèkhàn tóló àwè lí àlèkè. the youth itch feet APP Aleke

'The youth itched the feet of Aleke / itched Aleke's feet for her.'

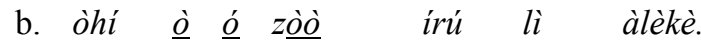

Ohi SC C pick.out lice APP Aleke

'Ohi is picking lice from Aleke / picking out Aleke's lice.'

c. ólì òkpòsò gbáló úhùnmi lí àlèkè. the woman tie.DS head APP Aleke

'The woman wrapped Aleke's head for her / wrapped the head of Aleke.'

Returning to recipient readings for the moment, we find only one type of possession relation. The prototypical recipient reading is defined by a direct object possessum linked to a 
pre-event subject possessor but a post-event dative possessor. There do not appear to be any li/ni marked recipient constructions defined by a direct object possessum linked to pre-event dative possessor and to a post-event subject possessor. Linkage works in only one direction for recipients but not for beneficiaries.

Consider now the following verbs and their possession relations. Dative complements interact with transitivity values for a limited number of verbs to reveal a distinctive grammatical pattern. The verb kuee 'present', in its ritualistic sense of 'betrothal', requires augmented transitive structures with $l i / n i$ (29a); simple transitive structures lacking $l i / n i$ are ungrammatical (29b).

a. élí édión kúéé ólì òkpòsò lí òhí. the elders present the woman APP Ohi

'The elders betrothed the woman to Ohi.'

b. *élí édiôn kúéé ólì òkpòsò. the elders present the woman 'The elders betrothed the woman.'

kuee's direct object, serving as notional possessum (ólì òkpòsò), undergoes a ritualized transfer to the dative complement's post-event possessor or recipient (óhi). Dative constructions of this nature pose no particular interpretation problem.

Equally unproblematic are structures with transitive kuee, a dative-marked complement and the indefinite subject pronoun $a$ 'one.'
(30)
à kúéé ólì okpòsò lí òhí.
one present the woman APP Ohi
'The woman was betrothed to Ohi.'

However, kuee also appears in an intransitive structure with a $l i / n i$ complement and indefinite subject pronoun $a$ 'one' (31). Despite the overt change in transitivity and the consequent loss of overt possessum, the dative complement continues to mark recipient. Few Emai verbs exhibit this pattern.
(31) à / *élí édioonn kúéé lí òjè. one the elders present APP Oje
'Oje got betrothed.'

In other Emai constructions, dative complements serve as neither recipient nor beneficiary. While these constructions assume no possession change, they do assume a possession relation. The intransitive verb gha 'be proportionately shaped' (32a) accepts a li/ni 
complement that expresses possessor (óli òkpòsò). As subject, gha requires the body-part noun égbè 'body.' The latter conveys possessum relative to dative possessor. No change in this relation is asserted or assumed.

a. égbé ghál lí ólì òkpòsò.

body be.proportionate APP the woman

'The body of the woman is shapely / The woman is well-proportioned.'

b. *égbé isì ólì òkpòsò ghá-ì.

body ASS the woman be.proportionate-F

'The body of the woman is shapely.'

$\begin{array}{rllll}\text { c. *ólì } & \text { okpòsò } & \text { ghá-í } & \text { vbí } & \text { égbè. } \\ \text { the } & \text { woman } & \text { be.proportionate-F LOC } & \text { body }\end{array}$

'The woman is shapely in her body.'

Absent a dative construction, one might have expected possessor and possessum to be subsumed under a single grammatical relation such as subject (32b). However, the latter is ungrammatical. Alternatively, one might have expected a disjoint grammatical expression of the possession relation, with possessor (óli òkpòsò) as subject and possessum (égbè) as locative complement (32c). This, too, is ungrammatical. The intransitive verb gha requires a disjoint grammatical expression of its assumed possession relation, with possessum as subject and possessor as dative. Given this obligatory linguistic disjuncture of the possession relation, gha li/ni constructions seem best viewed as manifesting an obligatory external possessor relation in which possessum and possessor, rather than occurring within a single constituent (égbé isì ólì òkpòsò, 32b), appear in distinct constituents and reference a more fully affected external possessor compared to a less fully affected internal possessor (Schaefer 1999). ${ }^{8}$ In

8 External possessors in Emai most often show a leftward shift of the possessor from the possessum, frequently characterized crosslinguistically as possessor raising (Shibatani 1994). In Emai, external and internal possessor constructions differ along an affectedness dimension in which external possessors are assumed to exhibit a conjoint relation of nonseparation vis-à-vis possessum and so be more fully affected by verb event, example (ia), while internal possessors exhibit a disjoint relation of separation relative to possessum and are assumed to be less affected by verb event, example (ib).

(i) a. ólì òkpòsò tóó ójé úkpùn á.

the woman burn Oje cloth CS

'The woman burned up (all of) Oje's cloth.'

b. ólì òkpòsò tóó úkpún ísì òjè á.

the woman burn cloth ASS Oje CS

'The woman burned up (some of) the cloth of Oje.' (continued) 
this respect, it is not simply a possessor role that is associated with dative à la Blake (2001) but an external possessor. And unlike Palmer's implicit claim, the dative marked possessor accompanying gha is more, not less fully affected as to shapeliness.

3.3. Additional Semantic Roles. In addition to recipients, beneficiaries and possessors, dative constructions express two additional semantic roles. $L i / n i$ establishes spatial colocation of human participants and temporal continuity of event elements when it marks addressee and locative reference point. The grammatical position associated with these roles requires a human referent and accepts a dative pronoun.

Attached to speaking verbs, dative complements mark the semantic role addressee with li/ni. Relative to a prototypical speaking event, the dative-marked addressee is assumed to be spatially co-located with the subject speaker, and the speaking event is assumed to be temporally continuous with a hearing event. Addressee expression requires a serial verb structure where the verb hon 'hear' is preceded by a clause anchored to a verb of speaking and a $l i / n i$ phrase (33).

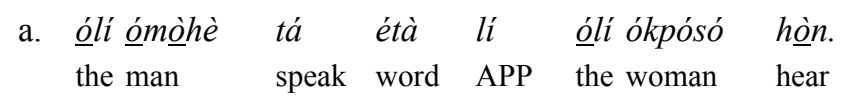

'The man spoke to the woman / spoke his words to the woman.'

$\begin{array}{llll}\text { b. óli ómònhè kpé itàn li } & \text { ólí ókpósó hòn } & \\ \text { the man } & \text { narrate saying APP } & \text { the woman } & \text { hear }\end{array}$

'The man narrated a saying to the woman.'

The dative complement of li/ni (óli ókpósó) must be coreferential with the understood subject of hon. The permissive modality (Palmer 2001) of the hon clause is signaled by right edge high tone of li/ni's complement (ólí ókpósó) and low tone on hon ${ }^{9}$

Absent the verb hon, transitive speaking verbs in construction with $l i / n i$ phrases are unacceptable (34a-b). When both $l i / n i$ and the verb hon are absent, that is no addressee role is articulated, speaking verb constructions are grammatical (34c-d).

$$
\begin{aligned}
& \text { a. *óli ómòhè tá étà lí ólì òkpòsò. } \\
& \text { the man speak word APP the woman } \\
& \text { 'The man spoke to the woman.' }
\end{aligned}
$$

With a stative verb like gha, our assumption is that the shift is rightward and marked by li/ni. Since a fully affected possessor is required by the meaning of $g h a$, an internal possessor relation is unacceptable. ${ }^{9}$ That the particle li/ni is not a complement designating a clause consisting of ólí ókpósó and hon is supported by pronoun shape in this construction, i.e. áin, the third person dative pronoun, not $\underline{o}$, the third person subject pronoun. 


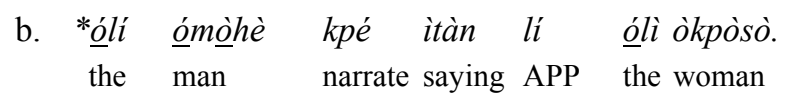

'The man narrated a saying to the woman.'

c. ólí ómộ̀è tá étà.

the man speak word

'The man spoke.'

d. óli ómòhè kpé itàn.

the man narrate saying

'The man narrated a saying.'

A second semantic role expressed by dative complements is locative reference point. This role surfaces for a select number of motion and position verbs. Constructions with these verbs signal a co-locational or dislocational spatial relation between a subject or direct object as figure (moving object or positional object) and dative as ground or reference point (Talmy 2000). With the dative construction and a moving object, one construes an assumed colocational relation as becoming dislocational, or an assumed dislocational relation as becoming co-locational. With dative and a non-moving or positional object, one asserts a given spatial configuration of positions as being co-locational. In other words, li/ni marks locative reference point regardless of whether participant co-location or dislocation is asserted.

Consider, first, those constructions that assume or assert co-location of subject and dative

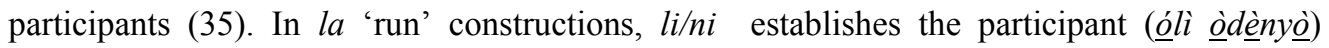
relative to which the direction of a running event leading to participant dislocation is asserted. In kpen ào 'be in front of' constructions, $l i / n i$ indicates the participant relative to whom a colocational configuration of participants is asserted.

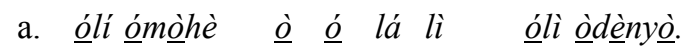
the man $\quad$ SC C run APP the drunkard 'The man is running from the drunkard.'

b. ólì òkpòsò kpẹn àó lí ólì ònwìmè. the woman be.next.to front APP the farmer 'The woman is in front of the farmer.'

Corresponding constructions with non-human nouns as locative reference points require distinct verbs or verb complexes, as indicated by comparison of $\underline{\underline{o} d e ̀ n y \underline{o}}$ 'drunkard' (35a) with èdá 'river' (36a) and ònwìmè 'farmer' (35b) with ìwè 'house' (36b). 

a. òhí $\underline{o} \underline{o} \quad z a ̀ \quad v b i ́$ édá là ráálè.
Ohi SC C belocated LOC river run move.away
'Ohi is running away from the river.'

$\begin{array}{lll}\text { b. } \underline{\text { óli }} \text { ómòhhè } & \text { rì̀ vbí isáó ìvè. } \\ \text { the man } & \text { be LOC front house }\end{array}$

'The man is in front of the house.'

For the position verb lahee 'hide,' Emai assumes a previous co-location relationship that links reference point to possessor. In non-causative structures (37a), intransitive lahee accepts a human noun as $l i / n i$ complement. The dative complement defines the locative perspective point from which to identify the hidden figure expressed as subject. In causative structures (37b), lahee admits a human noun as $l i / n i$ complement relative to the verb $n w u$ 'take hold' and its affected object. While dative remains as marker of locative reference point, direct object (ólí émà) rather than subject serves as figure or moving object.
a. ólí ómóhé láhèè lí ólì ònwìmè. the man hide APP the farmer
'The man hid from the farmer.'
b. ólí ókpósó ló nwù ólí émà láhèe lí ólì ònwimè. the woman PRED take.hold the yam hide APP the farmer 'The woman will hide the yam from the farmer.'

Let's look at these constructions individually. The non-causative structure in (37a) assumes that at some pre-event time subject (ólí ómóhé) and dative (ólì ònwìmè) participants were spatially co-located, with dative establishing the perspective point or ground from which to view the hiding event. At the time of utterance, the verb asserts a dislocated spatial relation between the subject figure and dative ground or reference point.

On the other hand, the causative structure in (37b) assumes that at some pre-event time the direct object figure (ólí émà) and dative ground (óli ònwìmè) existed as co-located participants. This structure leads one naturally to assume a pre-event link between direct object possessum and dative possessor. Thus the dative complement, while establishing the reference point perspective from which to construe the hiding event, also conveys possessor relative to direct object possessum.

'Hide' constructions stand in semantic contrast to 'show' constructions on the dimensions of possession and location. Asserting collocation and thus assuming a prior state of dislocation, 'show' constructions articulate with verb vbiee 'become visible, apparent' and 
verb re 'take.' Relative to lahee li/ni and $n w u$ lahee li/ni, we have, respectively, re égbè vbiee 'appear to' (38a) and re vbiee 'show something to' (38b).
a.

$\begin{array}{llllll}\text { ólì òkpòsò } & \text { ré } & \text { égbè } & \text { vbiéé } & \text { ivbiá } & \underline{o ́} \text {. } \\ \text { the woman } & \text { take } & \text { body } & \text { become.apparent.to children } & \text { her }\end{array}$
'The woman appeared to her children / made her body visible to her children.'

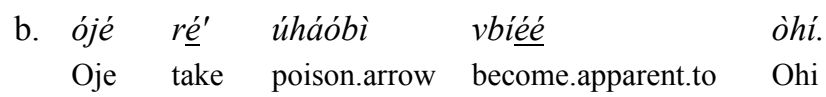

'Oje showed Ohi a poison arrow / made a poison arrow visible to Ohi.'

With another set of Emai verbs, the assumption of spatially co-located subject and dative participants combines with the notion of temporal durativity. Constructions with 'visit' verbs assume position change from spatially dislocated to spatially co-located. $L i / n i$ signals the locative reference point for these spatial construals as well as temporal longevity of the colocated state.

In simple intransitive constructions the verb vaan has the sense 'branch off, call, visit' (39a), while in transitive structures the verb ree has the sense 'visit' (39b).

a. òjè váán-ì.

Oje branch.off-F

'Oje visited / called.'



'A stranger visited Oje.'

'Visit' verbs in construction with dative $l i / n i$ or allative ye reveal significant differences in their temporal properties. Both dative and allative markers take a human noun complement as reference point. Their corresponding grammatical subjects convey event figure or moving object. With a $l i / n i$ complement ( $\partial h i)$, the construction sense is 'visit for some time,' dative indicating reference point from which to assess the figure's length of stay.

a. òjè váán lí òhí.

Oje branch.off APP Ohi

'Oje visited for some time / called on for some time / stayed with Ohi.'

b. é réé lí òhí.

they visit APP Ohi

'They visited Ohi for some time / paid a long visit to Ohi.' 
When these same verbs are augmented by ye, the construction sense is 'visit for a short time.' Allative ye specifies the reference point (òhi) from which to judge the subject figure's length of stay.

a. òjè váán yé òhí.

Oje branch.off move.to Ohi

'Oje briefly visited / called on / stayed with Ohi.'

b. inyókpá isi òjè réé yé òhí.

sibling ASS Oje visit move.to Ohi

'Oje's maternal sibling visited Ohi for a short time.'

The linear expression of events in discourse vis-à-vis dative and allative 'visit' constructions further supports the durativity contrast. In discourse, the expression of (42) would naturally follow (40a) with $l i / n i$ but not (41a) with ye.

(42) òjè méhén-ì.

Oje sleep-F

'Oje slept over'

A final construction demonstrates how problematic it can be to restrict $l i / n i$ complements to a single semantic role. Consider the verb khoo 'bathe.' As a simple transitive verb, it accepts a direct object participant (ólí $\underline{o} m \underline{o})$ linked to patient or affected object.

(43) óli òkpòsò khóó óli ómò.
the woman bathe the child
'The woman bathed the child.'

Khoo also accepts a dative complement. In the resulting construction, $l i / n i$ identifies beneficiary (òjè) and direct object again signals patient or affected entity (ólí ómó).

(44) óli òkpòsò khóó ólí ómò li li òjè. the woman bathe the child APP Oje

'The woman bathed the child for Oje.'

As a verb with no grammatically expressed direct object, khoo occurs with a li/ni complement (45a). 


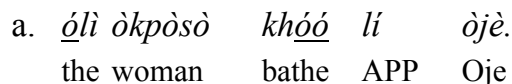

'The woman bathed Oje / did the bathing of Oje.'

b. òjè ò ó khònmé.

Oje SC C be.ill

'Oje is ill.'

However, the li/ni marked noun phrase has shifted semantic roles. Instead of beneficiary, it marks the patient or affected entity (i.e. the participant undergoing the bath). Dative-shift constructions of this type appear only under stringent contextual circumstances. They assume the dative-marked participant was unable to engage normally in the bathing activity, i.e had little control over its outcome. Relative to (45a), for instance, (45b) expresses a suitable constraining circumstance, i.e. Oje was bathed by the woman since he was ill. It is not that the dative-marked participant (ojè) is less fully affected by the bathing action; indeed, one could view the dative participant as more fully affected by virtue of the special circumstances suggested in (45b). Dative marking signals a reduced level of control and shifts the affected entity's assumed level of participation out of immediate focus (focus incorporating subject and direct object) and into event background. ${ }^{10}$ Even as a backgrounding device in discourse, dative marking with $l i / n i$ thus maintains spatial collectivity of human participants and their temporal continuity.

\section{Conclusion}

This paper has examined a range of structural relations in Emai marked by particle li/ni. Most of our attention has rested on the various semantic roles that Emai dative constructions mark with applicative li/ni. Emai verbs reveal how this particle, attracting [+human] nouns and its own set of pronouns, expresses the semantic roles recipient, beneficiary, possessor, addressee and locative reference point. Assuming that recipient, addressee and locative converge on Blake's (2001) "destination," we note that Emai's dative grammatical relation encompasses not only this semantic role but also his possessor and beneficiary roles. Moreover, through a transitive verb of bathing and a finely articulated context, we saw how "dative shift" and intransitive expression reveal the reduced control of an erstwhile direct object participant. Rather than being indirectly affected or less fully affected by the action of a verb à la Blake, the shifted participant was more completely affected by a co-participant.

\footnotetext{
${ }^{10} \mathrm{Li} / \mathrm{ni}$ 's reduced-engagement function of an erstwhile [+human] direct object appears parallel in some respect to preposition vbi's reduction of a quantity function for an erstwhile human affected object in partitive constructions (òjè é vbí óli émàè 'Oje ate from the food' vs. òjè éólí émàè 'Oje ate the food').
} 
More broadly speaking, $l i / n i$ tends to articulate the parameters of participant co-location and durative temporal effect. While these parameters register physical co-location and durativity in their prototypical condition, they also convey conceptual co-location and durativity. This range from physical to conceptual becomes manifest through dative constructions with verbs characterizing entity manipulation as well as verbs of speaking, motion, displacement and even physical property.

We also showed that the morphophonemic form designating dative in Emai was employed to convey grammatical relations of modification within noun phrases and subordination within complex sentences. In noun phrases, li/ni designated numeral complements with collective (co-locational) significance and temporal complements with a durative character. In clauses, li/ni identified purpose and result adjuncts, subjunctive S-complements, and purposive rhetorical interrogatives. How are we to interpret these formally unified but semantically diverse functions?

Our hypothesis, as expressed throughout preceding sections, is to view the structural relations designated by $l i / n i$ from the vantage point of grammatical perspective taking (Talmy 2000). We view the diverse semantic functions associated with $l i / n i$ as reflecting an abstract ground category within a larger figure-ground complex. For instance, the collective and temporal li/ni complements within a noun phrase signal a perspective which contrues the head noun referent as a spatial and/or temporal collective. Similarly, subordinate purpose and result clauses as well as subjunctive S-complements provide information of temporal contiguity from which to view and assess the assertion of a main clause (Croft 2001).

In the grammar of perspective taking, dative-marked grammatical relations can usefully be viewed as the ground participant against which to view the in-focus figure complex consisting of subject and direct object participants. Interpretation of the subject-direct object (or subjectverb) unit is functionally dependent on the dative constituent, as suggested by the backgrounding of sense relations for object manipulation verbs in dative constructions (ze 'scoop' compared to ze li/ni 'give by scooping'). Overall, we find that the grammatical particle designating dative in Emai reflects a semantic ground, one that expresses spatial collectivity of participants and/or temporal continuity of event elements. Additional scrutiny of verb types and their argument structure will no doubt reveal more about the dative relation in West Africa and the semantic interpretation it demarcates. 


\section{References}

Atoyebi, Joseph, Martin Haspelmath and Andrej Malchukov. 2010. Ditransitive constructions in Yorùbá. In Studies in Ditransitive Constructions: A Comparative Handbook, Andrej Malchukov, Martin Haspelmath and Bernard Comrie (eds). 145-165. Berlin: De Gruyter Mouton.

Bendor-Samuel, John. (ed.) 1989. The Niger-Congo Languages. New York: University Press of America.

Blake, Barry. 2001. Case (2nd Edition). New York: Cambridge University Press.

Croft, William. 2001. Radical Construction Grammar. Oxford: Oxford University Press.

Palmer, Frank R. 1994. Grammatical Roles and Relations. New York: Cambridge University Press.

Palmer, Frank R. 2001. Mood and modality (2nd Edition). New York: Cambridge University Press.

Schaefer, Ronald P. 1987. An Initial Orthography and Lexicon for Emai: an Edoid Language of Nigeria. Bloomington: Indiana University Linguistics Club.

Schaefer, Ronald P. 1999. On the properties of Emai possessors. In External Possession and Related Noun Incorporation Constructions, D. Payne and I. Barshi (eds). 449-472. Philadelphia: John Benjamins.

Schaefer, Ronald P. 2000. Possession transfer and Emai's classificatory verbs. Paper presented at the Annual Meeting of the Linguistic Society of America. Chicago.

Schaefer, Ronald P. and Francis O. Egbokhare. 1998. On tone and mood correlations in Emai. Research in African Languages and Linguistics 4 (1):1-13.

Schaefer, Ronald P. and Francis O. Egbokhare. (eds.) 1999a. Oral Tradition Narratives of the Emai People, Part I and II. Hamburg: LIT Verlag.

Schaefer, Ronald P. and Francis O. Egbokhare. 1999b. Postverbal complement particles in Emai. In 1998 Mid-America Linguistics Conference Papers, R. Schaefer and N. Lutz (eds). 196-207. Lawrence: University of Kansas.

Schaefer, Ronald P. and Francis O. Egbokhare. 2003a. Emai double object constructions. Afrika und Ubersee 86.1-33.

Schaefer, Ronald P. and Francis O. Egbokhare. 2003b. Emai sentence complements in typological perspective. In Linguistic Description: Typology and Representation of African Languages, John Mugane (ed). 257-269. Trenton, NJ: African World Press.

Schaefer, Ronald P. and Francis O. Egbokhare. 2007. A Dictionary of Emai: An Edoid Language of Nigeria. Köln: Rüdiger Köppe Verlag.

Schaefer, Ronald P. and Francis O. Egbokhare. 2010a. Language endangerment and Edo North as a residual zone. The Journal of West African Languages, special issue on language endangerment in Africa, edited by James Essegbey and Brent Henderson. 37.1.33-44. 
Schaefer, Ronald P. and Francis O. Egbokhare. 2010b. On Emai ditransitive constructions. In Studies in Ditransitive Constructions: A Comparative Handbook, Andrej Malchukov, Martin Haspelmath and Bernard Comrie (eds). 115-144. Berlin: De Gruyter Mouton. Schaefer, Ronald P. and Francis O. Egbokhare. nd. A Reference Grammar for Emai: A Nigerian Edoid Language.

Shibatani, Masayoshi. 1994. An integrated approach to possessor raising, ethical datives, and adversative passives. Proceedings of the Twentieth Annual Meeting of the Berkeley Linguistic Society. Berkeley: Berkeley Linguistic Society, 461-486.

Talmy, Leonard. 2000. Toward a Cognitive Semantics, Volumes I and II. Cambridge, MA: MIT Press.

Uwalaka, M.A.A.N. 1988. The Igbo Verb: A Semantico-Syntactic Analysis. Beiträge zur Afrikanistik Band 36. Wien: Institute für Afrikanistik und Ägyptologie der Universität Wien.

Williamson, Kay and Roger Blench. 2000. Niger Congo. In African Languages: An Introduction, Bernd Heine and Derek Nurse (eds). 11-42. New York: Cambridge University Press.

Ronald P. Schaefer

Department of English

Southern Illinois University Edwardsville

Edwardsville, IL 62026-1431

rschaef@siue.edu
Received: 3 February 2012

Accepted: 5 August 2012

Revisions: 14 December 2012 